\title{
Genetic Exploration on Crude Protein Estimation in Traditional Rice Landraces of Southern India
}

\author{
S. Velprabakaran ${ }^{*}$, S. Rajeswari ${ }^{2}$, P. Jeyaprakash ${ }^{3}$ and M. Raveendran ${ }^{4}$ \\ ${ }^{1}$ Department of Genetics and Plant Breeding, AC \& RI, Madurai, India \\ ${ }^{2}$ Department of Cotton, TNAU, Coimbatore-3, India \\ ${ }^{3}$ Department of Genetics and Plant Breeding, AD AC \& RI, Trichy, India \\ ${ }^{4}$ Department of Plant Biotechnology (CPMB), TNAU, Coimbatore-3, India \\ *Corresponding author
}

\section{A B S T R A C T}

\begin{tabular}{l}
\hline Key w o r d s \\
Indigenous rice, \\
Protein, \\
Variability, \\
GCV, PCV \\
\hline Article Info \\
\hline $\begin{array}{l}\text { Accepted: } \\
\text { 10 March } 2020 \\
\text { Available Online: } \\
\text { 10 April } 2020\end{array}$ \\
\hline
\end{tabular}

Rice (Oryza sativa L.) is the foremost important food crop in the world especially in Asiatic Continent. It is ranking second to the wheat among the most cultivated cereals in the world. Rice has widest germplasm collection than other cereal crops. It has to be made productive through several achievements in rice breeding programme, especially in sustainable food grain production with quality concern and it is undoubtedly the most important cereal of the world providing 21 per cent of global human per capita energy and 15 per cent of per capita protein. The mature rice grain, after removal of the hull (husk), again consists of the embryo and the starchy endosperm, surrounded by the seed coat, comprised of remnant tissues of testa and pericarp. The seed coat, embryo and the aleuronic layer from the bran is removed during the milling (often called polishing in rice) process. Most of the seed proteins are located in the rice bran. Thus is a need to collect, exploit and evaluate the untapped germplasms of Rice. Keeping this in view, an attempt was made to evaluate a set of thirty eight traditional land races with high yielding ruling varieties of protein content estimation this study will definitely impact for better parental selection in future crop breeding point of view.

\section{Introduction}

Rice (Oryza sativa L.) is the most important crop of India and it occupies 23.3 per cent of gross cropped area of the country. Rice contributes 43 per cent of total food grain production and 46 per cent of total cereal production. It continues to play vital role in the national food grain supply. It is the staple food of nearly half of the world's population. It ranks third after wheat and maize in terms of worldwide production. One third of Asia's rice production is consumed in China and one fifth in India (www.fao.org.in1992). 
The germplasm provides immense scope for wide variability. Genetic divergence is an efficient tool for an effective choice of parents for hybridization programme. Such study also selects the genetically divergent parents to obtain desirable combinations in the segregating generations. Protein is one of the most significant factors facing in developing world.

Only twenty per cent of the world people are affluent enough to have access to nutritious diet. Protein energy malnutrition (basic hunger or under nutrition) affects 850 million people worldwide. Most of the people eat the rice and rice based products, so improvise the protein content in rice is most important target. It is estimated that under nutrition is the cause of half of all the cases of child mortality. In India, over $50 \%$ of all children receive insufficient calories everyday to meet their potential growth and development requirements (Mahendra et al., 2004).

Oko et al., (2012) reported that about eighty per cent of all malnourished children in the developing countries that boasted food surpluses. With more than seventy per cent of the world's malnourished children, South Asia is expected to remain "Black Spots" of child malnutrition in 2020.

A substantial decrease in the availability of legumes over three decades, from an average of $64.4 \mathrm{~g}$ during the Pre-Green Revolution decade to about $33.6 \mathrm{~g}$ per capita per day during 1996 to 2002 in our country has been largely responsible for protein malnutrition. The quality of a rice protein is always determined by its amino acid profile. Studies conducted in the 1950s and 1960s on children recovering from protein energy malnutrition demonstrated that essential amino acids like lysine and tryptophan were important in improving nitrogen retention when cereals like wheat, rice or corn was the staple food
(Pellett and Ghosh, 2004). Riza et al., (2004) studied the precision of the study that showed that protein content of tested rice varieties ranged from 5.8 to 8.8 per cent for parboiled rice and from 5.5 to 7.5 per cent for unparboiled rice and also found that protein variations from 6.30 to 9.10 per cent in 438 rice cultivars, while rice germplasm lines of core collections had 5.00 to 9.50 per cent variation for protein in milled grains.

Deepa et al., (2008) reported that Njavara, a medicinal landrace of rice had higher protein when compared with Jyothi and IR64. They also stated that protein ranged from 4.30 to 18.20 per cent in different polished white rice samples. Banerjee et al., (2011) studied the protein content in 258 rice lines ranged from 4.91 to 12.08 per cent and five lines viz., Harad Guni, Koliha Cheriha, Hardeshi and Dudhiya Danwar were excelled more than 9.00 per cent protein. This implies not only the loss of a nutritionally valuable rice component in human diets but also a reduction of the quantity of rice available for human nutrition by around 10 to 15 per cent. In rice, polishing removes 15 per cent of the protein and also results in a significant loss of other nutrients

\section{Materials and Methods}

This investigation was carried out the protein estimation of traditional rice germplasm at the Department of Rice (Paddy Breeding Station), Centre for Plant Breeding and Genetics (CPBG), Tamil Nadu Agricultural University (TNAU), Coimbatore. The station is located at ${ }^{11^{\circ}} \mathrm{N}$ latitude and $77^{\circ} \mathrm{E}$ longitude with an elevation of $426.72 \mathrm{~m}$ above the mean sea level.

\section{Rice flour preparation for experiment}

The sample powder was grinded by using small volume $(150 \mathrm{mg})$ powder mixer for 
biochemical quality analysis. For analysis talc like powder sample was needed, when grinding the samples the sediment powder samples obtained were used for biochemical analysis.

\section{Crude protein content estimation}

For detecting the protein content (Fig. 1). The following reagents and buffers were prepared for extraction and estimation of protein from the rice flour. 2\% Sodium carbonate in $0.1 \mathrm{~N}$ Sodium hydroxide (Reagent A) 0.5\% Copper sulphate $\left(\mathrm{CuSO}_{4} \cdot 5 \mathrm{H}_{2} \mathrm{O}\right)$ in $1 \%$ potassium sodium tartrate (Reagent B) Alkaline copper solution: $50 \mathrm{ml}$ of reagent $\mathrm{A}$ and $1 \mathrm{ml}$ of reagent $\mathrm{B}$ were mixed prior to use (Reagent CFolin-Ciocalteau reagent (reagent $\mathrm{D}$ ): The commercial reagent was diluted 1:1 with water and used. Protein solution (Stock standard): $50 \mathrm{mg}$ of bovine serum albumin was taken accurately and dissolved in distilled water and made upto $50 \mathrm{ml}$ in a standard flask Working standard :10 $\mathrm{ml}$ of the stock solution was diluted to $50 \mathrm{ml}$ with distilled water in a standard flask Phosphate buffer 0.1 M (pH 7).

Rice flour samples $(500 \mathrm{mg}$ ) were taken and extracted with $5 \mathrm{ml}$ of buffer solution and centrifuged. The supernatant was collected separately. The residues were re extracted with $5 \mathrm{ml}$ buffer solution centrifuged twice and the collected supernatants were pooled and made upto $100 \mathrm{ml} .0 .5 \mathrm{ml}$ of sample extracts were pipetted out and made upto $1 \mathrm{ml}$ with distilled water. Different volumes of 0.2, $0.4,0.6,0.8,1.0 \mathrm{ml}$ of working standard solutions were pipetted into series of test tubes and made upto $1 \mathrm{ml}$ each with distilled water. A test tube with $1.0 \mathrm{ml}$ distilled water was used as blank. Then $5 \mathrm{ml}$ of reagent $\mathrm{C}$ was added to all the tubes thoroughly mixed and allowed it to stand for 10 minutes. Then $0.5 \mathrm{ml}$ of reagent $\mathrm{D}$ was added, mixed well and incubated at room temperature in the dark for 30 minutes. The absorbance of developed blue color was measured at $660 \mathrm{~nm}$ using UV- visible spectrophotometer (Elico, Mini Spec SL171) and readings were noted.

\section{Variability studies}

\section{Phenotypic and genotypic variances}

These were estimated according to the formulae given by Lush (1940).

Genotypic variance $\left(\sigma^{2} \mathrm{~g}\right)=\frac{\mathrm{M} 1+\mathrm{M} 2}{\mathrm{r}}$

Phenotypic variance $\left(\sigma^{2} p\right)=\sigma^{2} g+\sigma^{2} e$

\section{Phenotypic and genotypic coefficients of variability (PCV and GCV)}

For each character, phenotypic and genotypic coefficients of variability (PCV and GCV) were computed based on the method given by Burton (1952)

$$
\begin{aligned}
& \operatorname{PCV}(\%)=\frac{\sqrt{ } \sigma_{\mathrm{p}}^{2}}{\text { Grand mean }} \times 100 \\
& \operatorname{GCV}(\%)=\frac{\sqrt{ } \sigma_{\mathrm{g}}^{2}}{\text { Grand mean }} \times 100
\end{aligned}
$$

\section{Heritability}

Heritability $\left(\mathrm{h}^{2}\right)$ in a broad sense was calculated according to Lush (1940)

$$
=\frac{\sigma^{2} \mathrm{gh}^{2}}{\sigma^{2} \mathrm{p}} \times 100
$$

The range of heritability was categorized as suggested by Johnson et al., (1955) 


\section{Genetic advance}

Genetic advance was derived according to the method given by Johnson et al., (1955) for each character.

Genetic advance $=\frac{\sigma^{2} \mathrm{~g}}{\sigma \mathrm{p}} \times \mathrm{K}$

Where,

$\sigma^{2} \mathrm{~g}=$ genotypic variance

$\sigma \mathrm{p}=$ phenotypic standard deviation

$\mathrm{K}=$ selection differential, the value of which is 2.06 at $5 \%$ selection intensity. Genetic advance was expressed as percentage of mean by using the formula suggested by Johnson et al., (1955). The range of genetic advance as percent of mean was classified as described by Johnson et al., (1955).

\section{Results and Discussion}

This trait showed a range of variability from 7.63per cent (Arupatham samba) to 12.88 per cent (Kullakar) with a grand mean of 9.56 percent Table 1. The phenotypic and genotypic variances were 1.43 and 1.11 respectively. The phenotypic and genotypic coefficients of variations were 12.61 and 11.11 respectively (Fig.1).

Table.1

\begin{tabular}{|c|c|c|}
\hline & & $\begin{array}{c}\text { Grain } \\
\text { protein }\end{array}$ \\
\hline S.NO & Genotype & Content $(\mathbf{\%})$ \\
\hline $\mathbf{1}$ & Rajamudi & 10.33 \\
\hline $\mathbf{2}$ & Athurkitchali & 11.31 \\
\hline $\mathbf{3}$ & Thengai poo samba & 10.43 \\
\hline $\mathbf{4}$ & Valaan & 9.59 \\
\hline $\mathbf{5}$ & Kothandam & 8.79 \\
\hline $\mathbf{6}$ & Athira & 8.23 \\
\hline $\mathbf{7}$ & Karuvelli & 8.72 \\
\hline $\mathbf{8}$ & Karunkuruvai & 8.82 \\
\hline $\mathbf{9}$ & Arupatham samba & $\mathbf{7 . 6 3}$ \\
\hline $\mathbf{1 0}$ & Seeraga samba & 8.19 \\
\hline $\mathbf{1 1}$ & Kullakar & $\mathbf{1 2 . 8 8}$ \\
\hline $\mathbf{1 2}$ & Thondi & 11.66 \\
\hline $\mathbf{1 3}$ & Mappilai samba & 9.59 \\
\hline $\mathbf{1 4}$ & Marnellu & 9.38 \\
\hline $\mathbf{1 5}$ & Cheruli & 9.98 \\
\hline $\mathbf{1 6}$ & Kaliyan samba & 10.26 \\
\hline $\mathbf{1 7}$ & Kandagasala & 8.72 \\
\hline $\mathbf{1 8}$ & Kappakar & 9.38 \\
\hline $\mathbf{1 9}$ & Kottarasamba & 9.98 \\
\hline $\mathbf{2 0}$ & Karuppukavuni & 8.4 \\
\hline $\mathbf{2 1}$ & Nootripathu & 9.59 \\
\hline $\mathbf{2 2}$ & Vellaichithiraikar & 10.22 \\
\hline & & \\
\hline
\end{tabular}

\begin{tabular}{|l|c|c|}
\hline $\mathbf{2 3}$ & Sivappuchithiraikar & 8.75 \\
\hline $\mathbf{2 4}$ & Mohini samba & 8.58 \\
\hline $\mathbf{2 5}$ & Rasakadam & 8.93 \\
\hline $\mathbf{2 6}$ & Kakarathan & 8.3 \\
\hline $\mathbf{2 7}$ & Karthigai samba & 9.87 \\
\hline $\mathbf{2 8}$ & Ottadayan & 8.82 \\
\hline $\mathbf{2 9}$ & Sivappusirumani & 8.89 \\
\hline $\mathbf{3 0}$ & Kattikar & 9.56 \\
\hline $\mathbf{3 1}$ & Purple puttu & 8.4 \\
\hline $\mathbf{3 2}$ & Norungan & 9.03 \\
\hline $\mathbf{3 3}$ & Kallundaikar & 8.58 \\
\hline $\mathbf{3 4}$ & Velsamba & 8.68 \\
\hline $\mathbf{3 5}$ & Uppummolagai & 10.26 \\
\hline $\mathbf{3 6}$ & Kallundai & 9.52 \\
\hline $\mathbf{3 7}$ & Chinnapuncha & 10.22 \\
\hline $\mathbf{3 8}$ & Swarna & 11.13 \\
\hline $\mathbf{3 9}$ & C R 1009 & 10.71 \\
\hline $\mathbf{4 0}$ & IR 20 & 11.31 \\
\hline $\mathbf{4 1}$ & CO 51 & 10.43 \\
\hline & Mean & $\mathbf{9 . 5 6}$ \\
\hline & Maximum & $\mathbf{1 2 . 8 8}$ \\
\hline & Minimum & $\mathbf{7 . 6 3}$ \\
\hline & SE $(\mathbf{D})$ & $\mathbf{0 . 5 6}$ \\
\hline & CD 5\% & $\mathbf{1 . 1 4}$ \\
\hline & & \\
\hline & & \\
\hline & & \\
\hline & & \\
\hline & & \\
\hline & & \\
\hline
\end{tabular}




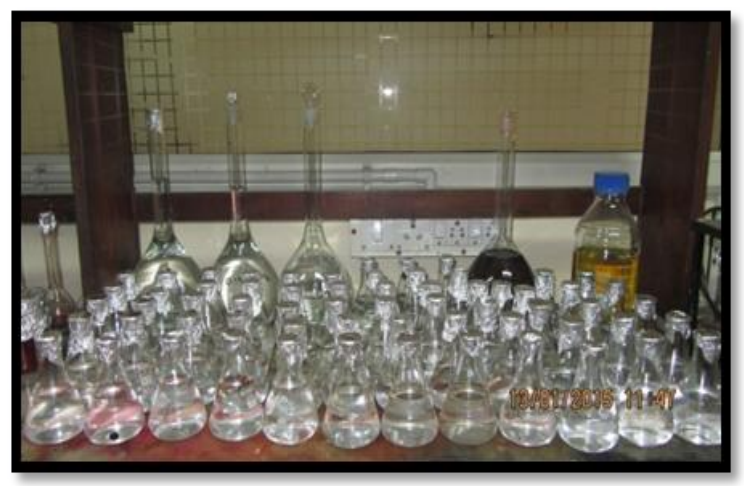

Fig.1 Rice flour digestion for protein estimation

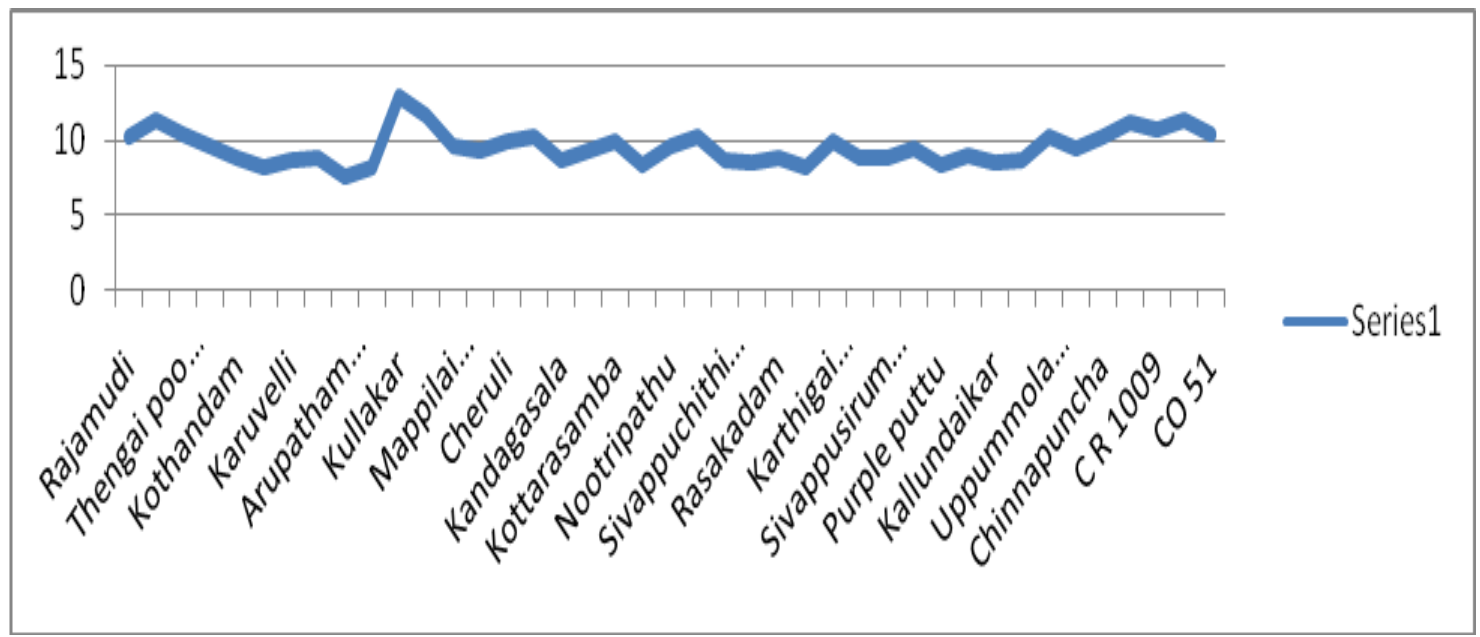

Fig.2 Mean performance of protein content of rice genotypes

High heritability of 78 percent and moderate genetic advance of 20.15 as a per cent of mean was recorded by this trait. The content protein showed high phenotypic and genotypic coefficient of variations. These results were in accordance with the findings of Luisa et al., (2008), Seyoum et al., (2012) and Shejul et al., (2013). Moderate GCV and PCV were recorded in the protein content and carbohydrate content (Fig. 2).

These results were accorded with the findings of Rao et al., (2010) and Paikhomba et al., (2014). And also protein content showed high heritability likewise the similar results were reported by Purusoathaman (2010), Ukaoma et al., (2013) and Paikhomba et al., (2014). Based on this study we explored the protein content in rice showed a range of variability.
It is high for Thondi, Kullakar, Thengai poo samba, athur kitchali, Kaliyan samba and low for Arupatham samba, Nootripathu, Kakarathan and Low for Kallundaikar kar, Kaaruppu kavuni, Arupatham samba, seeraga samba. Similar results were reported by in Riza et al., (2004) who found that protein variations from 6.30 to 9.10 per cent in 438 rice cultivars, while rice germplasms lines of core collections had 5.00 to 9.50 per cent variation for protein in milled grains.

Deepa et al., (2008) reported that Njavara, a medicinal landrace of rice had higher protein when compared with Jyothi and IR64. She also stated that protein ranged from 4.30 per cent to 18.20 per cent in different polished white rice samples. Banerjee et al., (2011) studied the protein content in 258 rice lines 
ranged which from 4.91 per cent to 12.08 per cent and five lines viz., Harad Guni, Koliha Cheriha, Hardeshi and Dudhiya Danwar were excelled more than 9.00 per cent protein.

\section{References}

Abodolereza, A. and P. Racionzer. 2009. Food Outlook: Global Market Analysis.

Banerjee, S., G. Chandel, N. Mandal, B.M. Meena and T. Suluja. 2011. Assessment of nutritive value in milled rice grain of some Indian rice landraces and their molecular characterization. Bangladesh J. Agric. Res., 36 (3): 369-380

Burton, G.W. 1952. Quantitative inheritance in grasses. Proc. 6th Int. Grassland Cong., 1: 277- 283

Deepa, G., K. Vasudeva Singh and N. Akhilender. 2008. Nutrient composition and physicochemical properties of Indian medicinal rice - Njavara. Food che., 106: 165-171.

Drea, S., D.J. Leader, B.C. Arnold, P. Shaw, L. Dolan and J.H. Doonan. 2005. Systematic spatial analysis of gene expression during wheat caryopsis development. Plant Cell, 17: 21722185 .

Fasahat, P., K.Muhammad, A. Abdullah and R. Wickneswari. 2012a. Proximate composition and antioxidant properties of Malaysianwild rice - Oryza rufipogon. Aust. J. Crop Sci. 6, 15021507

Johnson, H. W., H.F. Robinson and R.E. Corostock. 1955 Estimates of genetic and environmental variability in soybean. Agron. J. 47: 314-318.

Luisa, A. G. O., T. Lubin, F. Yongcai and S. Chuanqing. 2008. Genetic identification of Quantitative Trait Loci for contents of mineral nutrients in rice grain. J. Integr. Plant Biol., 10: 1744-7909

Lush, J.L. 1940. Intra-Sire correlation and regression of off- spring of doms as a method of estimating heritability of characters. Proc. estimating heritability of characters. Proceeding American Society Animal Production 33: 293-301

Mahendra, S., C. Ravi, B. Viswanathan, A. Gulati and S. Ramchander. 2004. Economic liberalization, programs and household food security: A case study of India IFPRI. Markets, Trade and Industry (MTI) Discussion, paper No.68

Oko, A.O., B.E. Ubi, A.A. Efisue and N. Dambaba. 2012. Comparative analysis of the chemical nutrient composition of selected local and newly introduced rice varieties grown in Ebonyi state of Nigeria. Int. J. Agric. For., 2 (2): 16-23.

Paikhomba, N., K. Arvind, A.K. Chaurasia and R. Prashant Kumar. 2014. Assessment of genetic parameters for yield and components in hrybrid rice and yield components in hybrid rice and parents. Journal of Rice Research 2:101-109

Pellet, P.L. and S. Ghosh. 2004. Lysine Fortification: Past Present and Future. Food and Nutrition Bulletin, 25: 2

Purusothaman, R. 2010. Genetic analysis for high iron and zinc content in rice (oryza sativa L.) grains.M.Sc., (Ag.). Thesis (unpubl.), TNAU, Coimbatore.

Rao, N., K. Bayyapa Reddy and Krishna Naik. 2010. Studies on genetic variability, correlation and path coefficient analysis in rice under saline soil conditions. The Andhra Agric. J., 57 (4): 335-338.

Riza, G., A. Ramos, R.V. Manaois, S.S. Escubio, G.D. Garcia, E.C. Arocena and L.S. Sebastian. 2004. Grain quality and iron density of Philippine rice cultivars. $4^{\text {th }}$ International Crop Science Congress.pp.527-531

Seyoum, M., S. Alamerew and K. Bantee. 2012. Genetic variability, heritability, correlation coefficient and path analysis for yield and yield related traits in 
upland rice (Oryza sativa L.). J. Plant Sci., 7 (1): 13-22

Shejul, M. B., Deosarkar, D. B., Kalpande, H. V., Chavan, S. K., Deshmukh, V. D., Dey, U. and Arbad, S. K. (2013). Variability studies for grain quality characters in upland rice (Oryza sativa L.). Afr J Agric Res, 8, 4872-4875
Ukaoma, A. A., P.I. Okacha and R.I Okechukwa. 2013. Heritability and character correlation among some rice genotypes for yield and yield components. Journal of Plant Breeder. Genet., 73-84

www.fao.org.in 1992.

\section{How to cite this article:}

Velprabakaran, S., S. Rajeswari, P. Jeyaprakash and Raveendran, M. 2020. Genetic Exploration on Crude Protein Estimation in Traditional Rice Landraces of Southern India. Int.J.Curr.Microbiol.App.Sci. 9(04): 1072-1078. doi: https://doi.org/10.20546/ijcmas.2020.904.127 